\title{
Bloom and Bust: ecological consequences of precipitation variability in aridlands
}

\author{
Daniel L. Potts • Greg A. Barron-Gafford • Bradley J. Butterfield • \\ Philip A. Fay $\cdot$ Kevin R. Hultine
}

Published online: 20 February 2019

(C) Springer Nature B.V. 2019

\begin{abstract}
An emerging consensus acknowledges increasing precipitation variability as a hallmark of anthropogenic global change (Luong et al. 2017; RoqueMalo and Kumar 2017). How aridlands, often characterized by episodic resource abundance and scarcity, will respond to future precipitation variability is of broad ecological interest and the inspiration for the focus of this special issue in Plant Ecology. Drawing on the economic expression, "Boom and Bust", which
\end{abstract}

Communicated by Daniel L. Potts, Bradley Butterfield, Philip Fay, Greg Barron-Gafford and Kevin Hultine.

D. L. Potts $(\bowtie)$

Biology Department, SUNY Buffalo State, Buffalo, NY, USA

e-mail: pottsdl@buffalostate.edu

G. A. Barron-Gafford

School of Geography and Development, The University of Arizona, Tucson, AZ, USA

\section{B. J. Butterfield}

Merriam-Powell Center for Environmental Research and Department of Biological Sciences, Northern Arizona University, Flagstaff, AZ, USA

\section{P. A. Fay}

USDA-ARS, Grassland Soil and Water Lab, Temple, TX, USA

\section{K. R. Hultine}

Department of Research, Conservation and Collections, Desert Botanical Garden, Phoenix, AZ, USA refers to cycles of economic prosperity and decline, our title, "Bloom and Bust" evokes the ecological impacts of extreme variations in rainfall in aridland ecosystems. Cycles of aridland resource abundance and scarcity are reflected in the adaptations and life histories of aridland plants, patterns of plant community composition in space and time, and in the biogeochemistry of aridland ecosystems (Noy-Meir 1973). Understanding the ecological consequences of an increasingly variable future climate is critical to maintaining the biodiversity of aridlands (Gherardi and Sala 2015) and to managing the goods and services they provide (Hamerlynck et al. 2016; Van Loon et al. 2016).

Like many topics in ecology, precipitation variability is complex, multifaceted, and can be difficult to delineate. We have identified four, key elements of precipitation variability (Table 1) that along with their interactions, influence the supply of, and demand for, plant available soil moisture which, in turn, shapes current and future ecological processes (Weltzin et al. 2003). Of these four elements, the most familiar to ecologists is variation in precipitation quantity, expressed as depth of precipitation. The ecological consequences of drought, loosely defined as a decline in the expected quantity of precipitation, is explored in some fashion by each of the papers featured in this special issue. Less explored and understood are the ecological consequences of shifts in rainfall seasonality (Zelikova et al. 2015), rainfall frequency (Liu 
Table 1 Elements of precipitation variability, their definition, and representative SI units

\begin{tabular}{ll}
\hline Element & Definition \\
\hline Quantity & Depth of precipitation $(\mathrm{mm})$ \\
Intensity & Depth of precipitation per unit time (e.g. mm day ${ }^{-1}$ ) \\
Seasonality & Occurrence and distribution of precipitation throughout the year \\
Frequency & Likelihood that precipitation of a given depth occurs; calculated from historical precipitation data \\
\hline
\end{tabular}

et al. 2017), and rainfall intensity (Kulmatiski and Beard 2013). The fact that all four of these elements of precipitation variability may shift in response to anthropogenic climate change underpins the urgency to understand their ecological consequences despite the logistical limitations of experimental design (Owens 2003; Beier et al. 2012).

The elements of precipitation variability interact with one another to influence aridland ecology. Here, we present a conceptual model which adopts a Darwinian perspective by focusing on how individuals, based on their life history and functional traits, are shaped by the elements of precipitation variability and how life history and functional trait variation subsequently impact allocation to growth, storage, reproduction, and interspecific interactions (Fig. 1). In this model, the ratio of plant-available soil moisture to atmospheric vapor pressure deficit (VPD) modulates the influence of precipitation variability on plants (McAuliffe 2003; Jenerette et al. 2012; Novick et al. 2016). We define "growth" as investment in new tissues, "storage" as allocation to stored reserves and "reproduction" as allocation to reproductive structures and investments in offspring. That our model includes allocation to "interspecific interactions" is a recognition of the critical role and resource-dependent nature of both above- and belowground interspecific interactions in aridlands (Butterfield et al. 2016; Zhang et al. 2016; Barron-Gafford et al. 2017). We acknowledge and incorporate the important contribution of antecedent conditions in shaping ecological responses to precipitation variability by incorporating a feedback loop, which illustrates how precipitation-mediated shifts in growth, reproduction, and mutualisms of individuals contribute to ecological memory and shape future responses to resource abundance and
Fig. 1 A conceptual diagram linking the elements of precipitation variability to ecological processes in aridlands

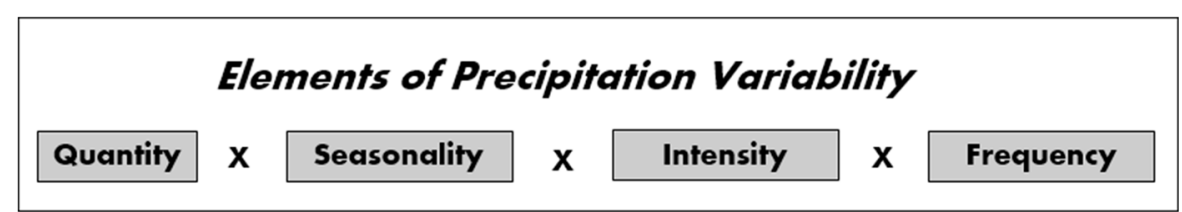

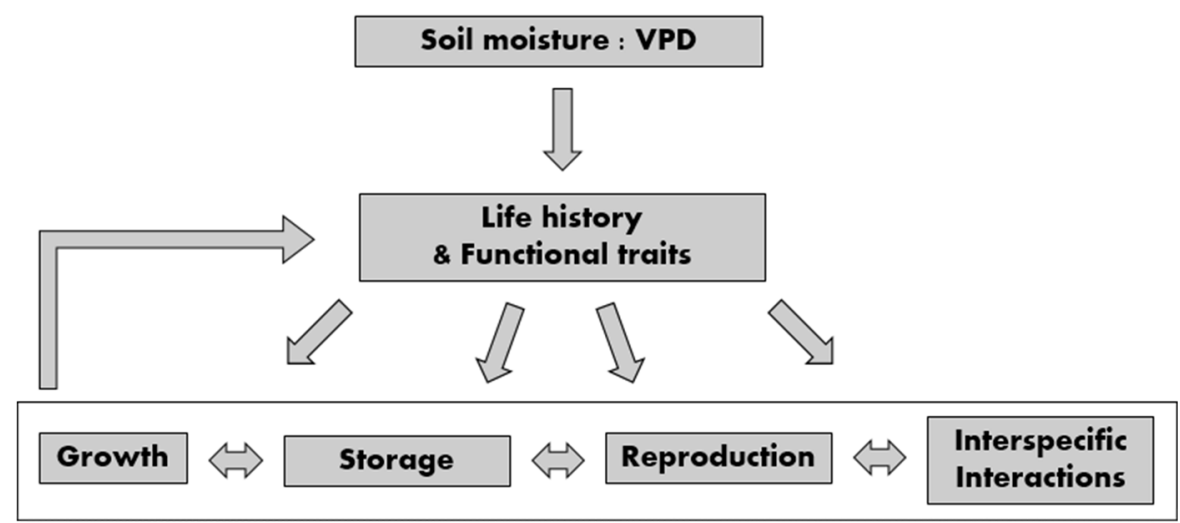


scarcity (Ogle et al. 2014; Peltier et al. 2016; Shen et al. 2016).

Our model acknowledges the mediating role of environmental temperature in shaping ecological responses to rainfall variability in two ways. The inclusion of seasonality as an element of precipitation variability recognizes that temperature limitation may constrain biological responses to precipitation (Potts et al. 2017). More directly, our model also includes consideration of VPD, a term that describes the atmosphere's demand for water vapor and is itself a function of air temperature. Many questions remain to be addressed regarding how short-term temperature variability as well as long-term temperature shifts associated with climate warming might interact with the elements of precipitation variability to impact growth, storage, reproductive allocation, and interspecific interactions in aridland ecosystems (Collins et al. 2016; Xu et al. 2016).

This special issue presents ecological research drawn from geographically diverse aridland ecosystems in China (Yue et al. 2019), Idaho (Reinhardt et al. 2019), southern California (Cleland and Goodale 2019; Kimball and Lulow 2019; Puritty et al. 2019), and the Iberian Peninsula (Jongen et al. 2019). Similarly, the research contained in this special issue employs both experimental manipulations and observational studies to inform theoretical and applied questions in plant ecology. Each paper presents a unique suite of ecological responses to rainfall variability, ranging from measurements of stable isotopes, physiological performance, and functional traits, to seed germination and seedling establishment, to comparisons of above- and belowground biomass allocation.

Each of the papers featured in this special issue speak to the theme of the ecological consequences of precipitation variability in their authors' own terms. For example, Yue et al. (2019) report results from a multi-site rainfall manipulation experiment which examined how the characteristics of drought shape the functional trait plasticity of steppe grasses along an aridity gradient which spans a portion of Inner Mongolia. Using a similar experimental framework, Puritty et al. (2019) present results from a rainfall manipulation experiment against the context of an unprecedented, multi-year drought in southern California to document the decline and subsequent recovery of native and nonnative species in a coastal shrubland and to demonstrate that multi-year drought followed by a year of abundant rainfall facilitates nonnative invasions. Working nearby, Kimball and Lulow (2019) explore the challenges and opportunities of grassland restoration using adaptive management tools against the backdrop of interannual precipitation variability. Their work describes how precipitation variability may overwhelm the effects of management activities to drive home the point that bet hedging strategies are crucial to increasing the likelihood of restoration success. In addition, working in semi-arid Mediterranean setting, but in this case, Portuguese rather than Californian annual grasslands, Jongen et al. (2019) report on the consequences of autumn drought and management practices on seedling establishment, drought recovery, and plant-fungal mutualisms. This work sheds light on the potential for complex, lingering effects of drought on productivity, species composition, and soil nutrient availability and that the consequences of precipitation variability extend belowground to influence plant mutualists.

The influence of precipitation seasonality on woody plants is a theme explored by two papers in this special issue. Reinhardt et al. (2019) report the structural, anatomical, and physiological responses of sagebrush (Artemisia tridentata) in response to a 20 -year long experiment that enhanced precipitation seasonality in a semi-arid shrub steppe. Results from this unusually long-term investigation provide novel insight into the important role of morphological plasticity in shaping structural traits and wood anatomy in response to longterm shifts in rainfall seasonality. Employing a greenhouse experiment, Cleland and Goodale (2019) describe results from a multi-species comparison of woody plants from southern California's Mediterranean-climate region in which they tested the ability of optimal allocation theory to predict root allocation responses to rainfall and nitrogen enhancement. In comparison with evergreen species, increased demand for nitrogen among deciduous species leads to enhanced root allocation which may constrain subsequent responses to rainfall variability in these communities.

By bringing together the perspectives of ecologists examining the impacts of rainfall variability from a range of perspectives and a range of aridland ecosystems, it is our hope that these papers can draw readers' attention to knowledge gaps in the role of biotic and abiotic legacies of precipitation variability, improve 
the conceptual linkages between field- and modelbased investigations, explore the dynamic linkage between above and belowground components of aridland ecosystems, and contrast the ecological consequences of cool- and warm-season drought in aridlands.

Acknowledgements Thank you to C. Holmgren for suggesting the title, "Bloom and Bust".

\section{References}

Barron-Gafford BA et al (2017) Impacts of hydraulic redistribution on grass-tree competition versus facilitation in a semi-arid savanna. New Phytol 215:1451-1461. https:// doi.org/10.1111/nph.14693

Beier C et al (2012) Precipitation manipulation experimentschallenges and recommendations for the future. Ecol Lett 15:899-911. https://doi.org/10.1111/j.1461-0248.2012. 0179

Butterfield BJ et al (2016) Does the stress-gradient hypothesis hold water? Disentangling spatial and temporal variation in plant effects on soil moisture in dryland ecosystems. Funct Ecol 30:10-19. https://doi.org/10.1111/1365-2435.12592

Cleland E, Goodale UM (2019) Co-limitation by nitrogen and water constrains allocation response to drought in deciduous and evergreen shrubs in a semi-arid ecosystem. Plant Ecol. https://doi.org/10.1007/s11258-018-0843-1

Collins SL et al (2016) Press-pulse interactions: effects of warming, $\mathrm{N}$ deposition, altered winter precipitation, and fire on desert grassland community structure and dynamics. Glob Change Biol. https://doi.org/10.1111/gcb.13493

Gherardi LA, Sala OE (2015) Enhanced interannual precipitation variability increases plant functional diversity that in turn ameliorates negative impact on productivity. Ecol Lett 18:1293-1300. https://doi.org/10.1111/ele.12523

Hamerlynck EP, Sheley RL, Davies KW, Svejcar TJ (2016) Postdefoliation ecosystem carbon and water flux and canopy growth dynamics in sagebrush steppe bunchgrasses. Ecosphere. https://doi.org/10.1002/ecs2.1376

Jenerette GD et al (2012) Organization of complexity in water limited ecohydrology. Ecohydrology 5:184-199. https:// doi.org/10.1002/eco.217

Jongen M, Förster AC, Unger S (2019) Overwhelming effects of autumn-time drought during seedling establishment impair recovery potential in sown and semi-natural pastures in Portugal. Plant Ecol. https://doi.org/10.1007/s11258-0180869-4

Kimball S, Lulow ME (2019) Adaptive management in variable environments. Plant Ecol. https://doi.org/10.1007/s11258018-0856-9

Kulmatiski A, Beard KH (2013) Woody plant encroachment facilitated by increased precipitation intensity. Nat Clim Change. https://doi.org/10.1038/nclimate1904

Liu WJ et al (2017) Repackaging precipitation into fewer, larger storms reduces ecosystem exchanges of $\mathrm{CO}_{2}$ and $\mathrm{H}_{2} \mathrm{O}$ in a semiarid steppe. Agric For Meteorol 247:356-364. https:// doi.org/10.1016/j.agrformet.2017.08.029
Luong TM et al (2017) The more extreme nature of north American monsoon precipitation in the southwestern USA as revealed by a historical climatology of simulated severe weather events. J Appl Met Clim 56:2509-2529. https:// doi.org/10.1175/jamc-d-16-0358.1

McAuliffe JR (2003) The interface between precipitation and vegetation: the importance of soils in arid and semiarid environments. In: Weltzin JF, McPherson GR (eds) Changing precipitation regimes and terrestrial ecosystems. University of Arizona Press, Tucson, pp 9-27

Novick KA et al (2016) The incresing importance of atmospheric demand for ecosystem water and carbon fluxes. Nat Clim Change. https://doi.org/10.1038/nclimate3114

Noy-Meir I (1973) Desert ecosystems: environment and producers. Ann Rev Ecol Syst 4:25-51

Ogle K et al (2014) Quantifying ecological memory in plant and ecosystem processes. Ecol Lett. https://doi.org/10.1111/ ele.12399

Owens MK (2003) Approaches and techniques of rainfall manipulation. In: Weltzin JF, McPherson GR (eds) Changing precipitation regimes and terrestrial ecosystems, University of Arizona Press, Tucson, pp 72-89

Peltier DM, Fell M, Ogle K (2016) Legacy effects of dourght in the southwestern United States: a multi-species synthesis. Ecol Monogr 86:312-326

Potts DL, Minor RL, Braun Z, Barron-Gafford GA (2017) Photosynthetic phenological variation may promote existence among co-dominant trees species in a Madrean sky island mixed conifer forest. Tree Phys 37:1229-1238. https://doi.org/10.1093/treephys/tpx076

Puritty CE et al (2019) Drought in Southern California coastal sage scrub reduces herbaceous biomass of exotic species more than native species, but exotic growth recovers quickly when drought ends. Plant Ecol. https://doi.org/10. 1007/s11258-019-00912-5

Reinhardt K, McAbee K, Germino MJ (2019) Changes in structure and physiological functioning due to experimentally enhanced precipitation seasonality in a widespread shrub species. Plant Ecol. https://doi.org/10.1007/ s11258-018-0845-Z

Roque-Malo S, Kumar P (2017) Patterns of change in high frequency precipitation variability of north America. Sci Rep 7:10853. https://doi.org/10.1038/s41598-017-10827-8

Shen W, Jenerette GD, Hui D, Scott RL (2016) Precipitation legacy effects on dryland ecosystem carbon fluxes: direction, magnitude and biogeochemical carryovers. Biogeoscience 13:425-439. https://doi.org/10.5194/bg-13-4252016

Van Loon AF et al (2016) Drought in the anthropocene. Nature Geosci 9:89-91

Weltzin JF et al (2003) Assessing the respons of terrestrial ecosystems to potential changes in precipitation. Bioscience 53:941-952

$\mathrm{Xu} \mathrm{Z}$ et al (2016) Ecosystem responses to warming and watering in typical and desert steppes. Sci Rep 6:34801. https://doi. org/10.1038/srep34801

Yue X et al (2019) Response of plant functional traits of Leymus chinensis to extreme drought in Inner Mongolia grasslands. Plant Ecol. https://doi.org/10.1007/s11258-018-0887-2

Zelikova TJ et al (2015) Seasonality of soilmoisture mediates responses of ecosystem phenology to eleated $\mathrm{CO}_{2}$ and 
warming in a semi-arid grassland. J Ecol 103:1119-1130. https://doi.org/10.1111/1365-2745.12440

Zhang B et al (2016) Arbuscular mycorrhizhal fungi regulate soil respiration and its response to precipitation in a semiarid steppe. Sci Rep 6:19990. https://doi.org/10.1038/ srep19990
Publisher's Note Springer Nature remains neutral with regard to jurisdictional claims in published maps and institutional affiliations. 